http://kitaibelia.unideb.hu/

ISSN 2064-4507 (Online) • ISSN 1219-9672 (Print)

(C) Department of Botany, University of Debrecen, Hungary

26(1): 31-48.; 2021

DOI: $10.17542 /$ kit.26.31

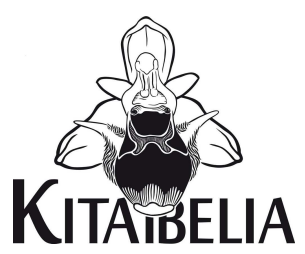

\title{
Florisztikai adatok Észak-Magyarországról II. Északi-Cserehát és Felső-Bódva-völgy
}

\author{
VojTKó András ${ }^{1} \&$ FARKAS Tünde ${ }^{2}$
}

(1) Eszterházy Károly Egyetem, Biológiai Intézet, H-3300 Eger, Leányka út 6.

(2) Aggteleki Nemzeti Park Igazgatóság, H-3759 Jósvafő, Tengerszem oldal 1.

\section{Floristic records from Northern Hungary II. North Cserehát and Upper Bódva valley}

\begin{abstract}
This paper presents new floristic data of 123 taxa from the regions of North Cserehát and Upper Bódva valley (Northern Hungary). Records were collected between 1995 and 2020. New occurrences of legally protected (e.g., Dactylorhiza incarnata, Eriophorum angustifolium, Lycopodium clavatum) and not protected but locally rare or data-deficient species (e.g., Artemisia annua, Carex remota, Cirsium pannonicum, Cyperus fuscus, Genista pilosa, Melampyrum cristatum Ranunculus flammula, Scorzonera purpurea, Silene noctiflora) are presented.
\end{abstract}

Keywords: North Hungarian Mountains, occurrence data, rare species, vascular flora

Összefoglalás - Összeállításunkban az Északi-Cserehát és a Felső-Bódva-völgy területéről 1995 és 2020 között gyűjtött, korábbi publikációinkból kimaradt adatainkat közöljük, 123 fajra vonatkozóan. Publikáljuk néhány, a területről eddig nem közölt, vagy ritka faj adatát (pl. Artemisia annua, Genista pilosa, Ranunculus flammula, Scorzonera purpurea, Silene noctiflora), illetve kitérünk olyan adathiányos, de gyakoribb fajra is, mint a Carex remota, Cirsium pannonicum, Cyperus fuscus, Melampyrum cristatum. Néhány védett faj (Dactylorhiza incarnata, Eriophorum angustifolium, Lycopodium clavatum) új lelőhelyére is rábukkantunk.

Kulcsszavak: Északi-középhegység, elterjedés, előfordulási adatok, edényes flóra, ritka fajok

\section{Bevezetés}

A tágabb értelemben vett Cserehát tájegység a Bódva és a Hernád folyók által közrevett terület. A szükebb értelmezés és a kistájfelosztás alapján északon az Aggtelek-Rudabányaihegység középtájon belül a Tornai-dombság és Szalonnai-hegység található. Ettől délebbre, az Észak-Magyarországi-medencék középtáj alá sorolt Szendrői-rögvidék, Rakacai-völgymedence, Keleti-Cserehát és Nyugati-Cserehát résztájakra tagolt a terület (DövéNYI 2010). Mindkét felosztás elterjedt, azonban az utóbbi részletezést egyszerüsítve, az első gondolatsor szerinti felfogás nyomán adunk rövid jellemzést a Cserehátról és ez alapján foglaljuk össze a florisztikai adatainkat is.

Észak-Magyarország botanikai szempontból egyik legkevésbé kutatott részéről van szó, arról a területről, amelyben már alig találni természetes, vagy természethez közeli erdőt, annál több a szántó, a parlag, a kaszáló, az ültetvény és a fátlan - cserjésedő domboldal. Domborzatára jellemző a dombsági hátak és a széles, tál alakú völgyek szelíd hullámzása - váltakozása. Legmagasabb pontja az Irotától északra levő Kecske-pad (340 m), legmélyebben pe- 
dig a Vadász-patak völgye van (125 m), Alsóvadásztól délre. A felszínt fóként a pleisztocén korú agyag, illetve még homok, márga és kavics, néhol lösz takarja. A Rakacai-völgymedence peremén fordul elő mészkő („rakacai márvány”), amely fontos, néhány főként itt előforduló faj kis populációjának megjelenéséhez (pl. Dictamnus albus, Iris aphylla subsp. hungarica, Pulsatilla grandis stb).

A dombvidéki táj potenciális vegetációja túlnyomó részben a cseres-tölgyes és az északi részeken, a Rakaca-völgy és az országhatár között a gyertyános-tölgyes. Egykor nagyrészt erdővel borított terület volt, melyet a múlt század nagy erdőirtásainak nyomán megszüntettek. Jelenleg a Cserehát területének csupán kb. 20\%-át fedi erdő (JAKUCS 1961). Ez az erdő főként cseres-tölgyes, melyet a völgyekben és az északi lejtőkön néhol extrazonális gyertyános-tölgyes vált fel. Gyakran találkozni akácosokkal és esetleg fenyvesekkel. Boldva és Alsóvadász térségében a száraz-hűvös klímára jellemző mezei juharos-tölgyes is megtalálható, mely a gyertyános-tölgyes hegyvidéki fajokban szegényebb és általában gyertyán nélküli változata. A zonális erdőtársulásokban a szokványos fajkészlet található, mindemellett az állományok jelentős része rontott és akácosított. A dombvidék déli, lösszel fedett részén egykor tatárjuharos-tölgyes díszlett, ennek maradványait Szikszó és Aszaló környékén tanulmányozhatjuk. A Cserehát legnagyobb része ma legelő, kaszáló, illetve gyenge minőségú szántóföld. A terület növényzetének jellegzetességei a folyó- és patak-völgyeket kísérő mocsár és láprétek, magassásosok, magaskórósok is, melyek sokszor mozaikolnak bokorfüzesekkel és éger- vagy füzligetek maradványaival. Ezek a nedves élőhelyek talán a terület legértékesebb fajkészletű részei.

Az Északi-Csereháttal határos Felső-Bódva-völgy területéről az első adatokat THAIsz Lajos (1910, 1911, 1937) közölte Komjáti és Bódvalenke községhatárral. Számos fajt gyüjtött is a területen pl. Catabrosa aquatica. Budai József 1909-es, 1914-es gyűjtései és irodalmi közlései tanúskodnak róla, hogy többször járt a területeken. Rakaca és Rakacaszend között gyüjtött pl. Echium maculatum-ot és Chamaecytisus albus-t. 1914-ben közli a Dictamnus albus-t a Rakaca-völgyből, valamint a Bódva-völgyben Szendrőládnál megtalalálja az Iris aphylla subsp. hungarica-t (BuDAI 1914). Soó et al. (1943) is számos Budai adatot tesz közzé. Boros Ádám több alkalommal is ellátogatott a területre $(1922,1926,1937,1938,1943)$, adatai között szerepel a Komjáti és Bódvaszilas közötti szántóról az Adonis aestivalis, illetve nedves rétről pl. az Utricularia vulgaris és az Orchis palustris. Jakucs Pál 1948-1953 között számos növényt gyüjtött a területen, részben a Bódva-völgyben, pl. Szalonnánál, részben a Cserehátban a Rakaca-völgyben. Herbáriumi lapjai az MTM Növénytárban és a Debreceni Egyetem Herbáriumában találhatók. Megemlítjük a büttösi Persicaria bistorta adatát (1952, BP), valamint a Rakaca-völgyben talált Fritillaria meleagris-t és Aconitum vulparia előfordulást (1952, BP). A térségből származó adatait később közli is (JAKUCS 1952, 1961). Nagy Miklós és Papp Mária a Rakaca-völgy felső szakaszát kutatta, kiemelve az Alchemilla monticola előfordulását. A Rakaca forrásvidékéről közölték például az Achillea ptarmica és a Carex canescens fajokat, valamint vizsgálták a Fritillaria meleagris morfológiai jellegzetességeit és populációdinamikáját is (NAGY \& PAPP 1992, 1996, 2003, PAPP \& NAGY 2003). Endes Mihály is több publikációt írt területről, valamint több kutatótársával együtt feldolgozták a Rakaca-patakvidék természeti értékeit (ENDES 1995a,b, 1996, 1997, 2003a,b, ENDES et al. 2003a,b). Vojtkó András első adatai 1995-ben jelentek meg, amikor a Sonchus palustris előfordulásáról írt szerzőtársával, több Bódva-völgyi és csereháti település határából (Bódvalenke, Szalonna, Meszes, Krasznokvajda, Rakaca, Tornaszentjakab, Alsógagy, Felsőgagy) (BÁNKUTI \& VojTKó 1995). Ezt követően Marschall Zoltánnal közösen publikálták a térség erdeiben végzett kutatásaik legfontosabb eredményeit (VojTKó \& MARSCHALL 1997), így többek között a Tornaszentjakab melletti Bodolai erdő kisavanyodó foltjaiból a Lycopodium clavatum-ot és a Vaccinium myrtillus-t. 2004ben hívta fel a figyelmet a Senecio doria-ra a Bódva-völgyben (VojтKó 2004), majd később, a jelenlegi cikksorozat első részében még számos előfordulással gazdagította a Cserehát flórá- 
ját (VојтKó 2008). Farkas József florisztikai adatgyűjtései hiánypótlóak voltak a térségben, pl. 1996-ban 48 védett faj adatát adta közre, majd 2000-ben készült kutatási jelentésében 105 fajról készített előfordulási térképet, de sajnos ezt a munkát végül nem publikálta. Olyan új előfordulások kötődnek a nevéhez, mint pl. az Iris aphylla subsp. hungarica Rakaca és Meszes községhatárokban, valamint Tornaszentjakab mellett az Eriophorum latifolium és Pamlény mellett, a Janka-patak völgyben megtalált Fritillaria meleagris. 1994-ben ő találta meg a hidvégardói Szent-János kövön az Onosma tornense új előfordulását, melyet végül Simon Tibor határozott meg (FARKAS J. 1996). A Csereháti Tájvédelmi Körzet tervezett védetté nyilvánításának előkészítése elsősorban Salamon Gábor és Penksza Károly nevéhez fűződik. Alapozó kutatások során felmérték a terület legértékesebbnek ismert részeit és számos új eredménynyel gazdagították ismereteinket. A Matricumra új fajként találták meg a Carex buxbaumii-t Hidvégardó mellett. Sok ritka és értékes növény előfordulását közölték Tornaszentjakab, Viszló, Debréte és Pamlény községhatárból is (Penksza \& SAlamon 1997a,b). Penksza 1996os és 1997-es kutatási jelentéseinek adatai sajnos nem jelentek meg nyomtatásban. PENKSZA \& MALATiNSZKY (2010) a későbbikeben is gyűjtöttek pár szórványelőfordulást a területről. A közelmúltban VIRÓK et al. (2004, 2011) és VIRóK \& FARKAS R. (2007) folytatták a terület flórájának feltárását és sok új fajt közöltek a tájegységekből, így Tornaszentjakabról pl. Eleocharis uniglumis-t és Taraxacum palustre-t, de rábukkantak egy ritka adventív fajra, az Epilobium ciliatum-ra is a Szirákó-völgyben. A Bódva-völgyben Bódvalenkénél közölték pl. a Hottonia palustris és a Lindernia procumbens előfordulását. Az utóbbi években MolNÁR Cs. (2014) és MoLNÁR Cs. et al. $(2016,2018)$ számoltak be új adatokról és gazdagították a terület flóráját pl. Debréte: Inula helenium, Szászfa: Persicaria bistora és Iris sibirica.

\section{Anyag és módszer}

Jelen közleményünkben elsősorban a Cserehát északi részéről (Büttös, Debréte, Meszes, Pamlény, Szemere, Tornaszentjakab, Viszló, Rakaca) valamint a Felső-Bódva-völgyből (Bódvelenke, Hidvégardó) 1995-2020 között gyűjtött, előző közleményeinkből kimaradt florisztikai adatainkat gyüjtöttük össze, de a publikáció más tájegységekből is tartalmaz néhány szórványadatot (Alsógagy, Boldva, Sajóecseg Szalonna, Szakácsi). Enumerációnkban a védett fajokon kívül a lokálisan ritka fajok, a területről kevés adattal rendelkező gyakori elemek, valamit az özönnövények előfordulásait adjuk közre.

A fajok sorrendje alfabetikus, megnevezése KIRÁLY (2009) munkáját követi. A földrajzi nevek tekintetében az Aggteleki Nemzeti Park Igazgatóság dűlőkataszteri térképét vettük alapul, továbbá néhány esetben az EOTR 1:10 000 topográfiai térképek földrajzi elnevezéseivel pontosítottuk az előfordulások helyét. Az egyes fajok előfordulási adatai után feltüntettük az adatgyüjtő monogramját, a megtalálás évszámát, valamint a Közép-Európai Flóratérképezés (KEF) módszertana (NIKLFELD 1971, KIRÁLY 2003) szerinti kvadrátszámokat is. A szakirodalmi hivatkozásoknál elsősorban a fő vizsgálati területre vonatkozóan megjelent tudományos publikációkra támaszkodtunk. Az enumeráció összeállításánál a „Flóraatlasz” (BARTHA et al. 2015 [1]) adatait, beleértve az online adatbázist is csak korlátozott mértékben tudtuk felhasználni, mivel az ott szereplő adatok aggregáltsága miatt a pontos térképi lokalitások sokszor nem beazonosíthatók, nem visszaellenőrizhetők, és sokszor egyetlen településnév szerepel (a kvadrát „neve”), vagy hiányzik a gyüjtő, így az általunk talált részletes adatokkal nem összevethetők. Amennyiben a fajnak van máshol közölt irodalmi forrása, azt nem soroltuk fel újra a „Flóraatlasz adatai” között. Az online frissülő „Flóraatlasz”-ra (BARTHA et al. 2020) „MFA online” rövidítéssel utalunk.

Amennyiben herbáriumi példánnyal is rendelkezünk a fajról annak rövidítését szintén jelöltük az évszám után. A közölt fajok vonatkozásában átnéztük az MTM Növénytár Herbari- 
um Carpato-Pannonicum gyűjteményét és a Debreceni Egyetem Herbáriumát is. Az innen ismertté vált korábbi gyüjtésekre az adatsorok végén utalunk.

Az adatsorban használt rövidítések:

BP: Magyar Természettudományi Múzeum, Növénytár, Budapest

DE: Debreceni Egyetem Herbáriuma

FT: Farkas Tünde

FR: Farkas Roland

HK: Hudák Katalin

\author{
MCs:Molnár Csaba \\ MZ: Marschall Zoltán \\ PK: Penksza Károly \\ SZF: Szűts Fanni \\ VA: Vojtkó András \\ VV: Virók Viktor
}

\section{Enumeráció}

Adonis vernalis L. - Pamlény: Kúton-felüli-dűlő, sztyepréten (FT, 2000) [7591.2]. Irod.: Korábban a településről csak a Bogoly-völgyből volt adata (FARKAS T. 2011). Az ÉszakiCserehátból Meszes: Jóna-hegyről is közölték (FARKAS J. 1996, VojTKó \& MARSCHALL 1997). MFA online: Ebből a négyzetből eddig nem volt ismert adata.

Adoxa moschatellina L. - Viszló: Barveny-hegy (VA, 1996) [7491.3]. Irod.: A területről Tornaszentjakab: Katalin-majorból jelzi VoJTKó \& MARSCHALL 1997-ben, valamint Rakacaszend: Farkas-kút és Csonka-erdő (VIRóK et al. 2011) és Szendrő: Nagy-Csákány-lápán (VIRóK \& FARKAS R. 2007) vannak még előfordulásai. MFA online: Becskeháza (SZF, VV, 2003) és Tornaszentjakab (VV, SZF, 2004). Az Északi-Cserehátban csak ebben a négyzetben fordul elő.

Agrostis capillaris L. - Viszló: Fás-legelő (FT, 2009) [7591.1]. Irod.: ENDES et al. (2003a) és ENDES (2003b) Tornabarakonyból írja. MFA online: Perecse (VV, 2004). A négyzetből nincs korábbi adata. Sovány száraz gyepekben gyakori a területen, de adathiányos.

Alisma plantago-aquatica L. - Pamlény: Bogoly-völgy (FT, 2009) [7491.3]; Viszló: Bogolyvölgy (FT, 2009) [7591.1]. Irod.: Korábbi irodalmi forrásokban Büttös, Litka, Szemere: Rakaca-völgyben, Viszló: Viszlói-patak és Tornaszentjakab: Szirákó-völgyben jelzik (ENDES et al. 2003a, NAGY \& PAPP 1996). Bódvalenkéről THAISZ (1937) írja. MFA online: Becskeháza (SZF, VV, 2003) és Tornaszentjakab (VV, SZF, 2004) és név nélkül Rakaca (2004).

Allium vineale L. - Viszló: Felső-rét száraz gyepjében (FT, 2020) [7591.1]. MFA online: Becskeháza (SZF, VV, 2003) és Tornaszentjakab (VV, SZF, 2004), Büttös (FR, 2004). A területen adathiányos faj.

Ambrosia artemisiifolia L. - Pamlény: Bogolyi-erdő (FT, 2009) [7491.4], Bogoly-völgy (FT, 2009) [7491.3], Tuskós (FT, 2009) [7591.1], Csonkás-dűlő és Topolyka-hegy (FT, 2009) [7491.4]. Irod.: ENDEs et al. (2003a) csak Rakaca és Rakacaszend, valamint Viszlói-patak mellől írják. Szántókon és vadászati szórókon terjedő adventív gyom. Bár a „Flóraatlasz” adatai szerint a területen elég közönséges, de a 7591.1 kvadrátból nincs adata.

Anemone ranunculoides L. - Viszló: Barveny-hegy (VA, 1996) [7491.3]; Rakaca: Király-hegy északnyugati oldala (VA, MZ, 1996) [7591.1]. Irod.: A területről Tornaszentjakab: Katalinmajorból (VoJTKó \& MARSCHALl 1997) van közlése. Herb.: Rakacaszend: Kopasz-hegy, Jakucs (1952, BP). MFA online: Becskeháza (SZF, VV, 2003) és Tornaszentjakab (VV, SZF, 2004).

Angelica sylvestris L. - Bódvalenke: Kotra (VA, PK, 1996) [7490.4]; Büttös: Rakaca-völgy (VA, 1996) [7592.1]; Pamlény: Bogoly-völgy mocsárrétjén (FT, 2009) [7491.4]; Tornaszentjakab: Sas-patak-völgye (VA, PK, 1996) [7491.3]; Tornaszentjakab: Kanyiszló-völgy (FT, 2009) [7491.3]; Szemere: Szőlők-alatti-völgy, lápréten (VA, 1996) [7592.2]; Viszló: Cseres (VA, 1996) [7591.1]. Irod.: Büttös: Bakonyi völgy, Debréte, Keresztéte, Meszes, Rakaca-völgy, Janka-patak völgye, Szirákó-völgy és a Viszlói-patak völgye (ENDES et al. 2003a, NAGY \& PAPP 1996, 2003); Bódvalenke: Kapitány-rét, Grajzinger-rét, Partos-oldali-mocsár 
(VIRóK et al. 2016). MFA online: A Flóraatlasz szerint gyakori, mivel a vizsgált területen minden kvadrátban flóratérképezett.

Antennaria dioica (L.) Gaertner - Viszló: Fás-legelő kisavanyodó rétjén (FT, 2000) [7591.1]. Irod.: VojTKó \& MARSCHALL (1997) Viszló: Vigyorból, VIRÓK \& FARKAS R. (2007) legközelebb Fancsalról közli. MFA online: Perecse (VV, 2004). A térségben ritka.

Anthemis arvensis L. - Boldva: Kender-földek, Sajóecseg-Boldva közötti vasúti töltés mentén (FT, 2003) [7790.4]. Irod.: A Felső-Bódva-völgyből Bódvalenke és Komjáti határából ismert (ThaISz 1937). Herb.: Budai Józsefnek Meszes mellől van egy herbáriumi lapja 1909ből (BP). Hulják Szendrőládnál gyűjtötte (1937, BP). MFA online: Sajóecseg, Sajópálfala (FT, 2003, 2004); Hangács (MCS, 2012). Szántókon gyakori, ugyanakkor kevés adata van.

Anthoxanthum odoratum L. - Viszló: Cseresi-földek (FT, 2009) [7591.1]. Irod.: Viszló mellól a Viszlói-patak völgyéből Pamlényből és Büttösről, Rakaca: Proszniszkó-völgyből, Szászfa és Szemere határából ENDES et al. (2003a) és NAGY \& PAPP (1996) közlik. Rakacáról (MoLNÁR Cs. et al. 2018), míg a Felső-Bódva-völgyből Komjátinál THAISz (1937) írja. MFA online: A területen gyakori, minden flóratérképezési kvadrátba szerepel.

Arabidopsis thaliana (L.) Heynh. - Boldva: Kender-földek, Sajóecseg-Boldva közötti vasúti töltés (FT, 2003) [7790.4]. MFA online: Borsodszirák (VV, 2004).

Artemisia absinthium L. - Boldva: Kender-földek, Sajóecseg-Boldva közötti vasúti töltés mentén (FT, 2003) [7790.4]. Irod.: Hidvégardó: Tobolyka, Kút-fej, Alsó-Tapolca, Bódva (VIRóK et al. 2016). Herb.: Felső-Bódva-völgy: Hidvégardó: Szent János-hegy Jakucs (1953, BP). MFA online: Sajópálfala, Sajóecseg és Arnót (FT, 2004), Tornabarakony (VA, 2004). A faj nem ritka a területen, de adathiányos.

Artemisia annua L. - Boldva: Kender-földek, Sajóecseg-Boldva közötti vasúti töltés mentén (FT, 2003) [7790.4]. Irod.: Ónodról TAKÁcs et al. (2013) közli. MFA online: Sajóecseg (FT, 2003). Észak felé mindezidáig nem terjed a Cserehátban.

Asplenium trichomanes L. - Meszes: Vasbánya déli, meredek sziklás oldala (VA, 1996) [7590.4]; Rakacaszend: Gerenda-vigyor (VA, 2020) [7591.1]; Rakaca: Király-hegy északnyugati oldala (VA, MZ, 1996) [7591.1]. Irod.: THAISZ (1937) Bódvalenkei adata valószínúleg Alsó-hegyre vonatkozik. MFA online: Rakacáról (név nélkül: 2004).

Athyrium filix-femina (L.) Roth - Viszló: Barveny-hegy (VA, 1996) [7491.3]; Büttös: Rakacavölgy (VA, 1996) [7592.1]. Irod.: EnDES et al. (2003a) Rakacaszend: Debréte-patak, Tornabarakony és Szemere mellől jelzi, THAISz (1937) Bódvalenkén írja, ezen kívül Hidvégardó: Alsó-rét, Sas-patak (VIRóK et al. 2016) mellől közölték. MFA online: Perecse (VV, 2004), Büttös (FR, 2004), Tornabarakony (VA, 2004).

Betula pendula Roth - Debréte: Nyírjes (VA, 1996) [7591.1]; Tornaszentjakab: Bodolai-erdő (VA, 1996) [7491.4]. Irod.: Korábban Viszló, Pamlény, Rakaca, Rakacaszend és Szemere mellől jelezték (ENDES et al. 2003a, NAGY \& PAPP 1996). MFA online: Perecse (VV, 2004), Tornaszentjakab (VV, SZF, 2004), Szászfa (név nélkül: 2004), Tornabarakony (VA, 2004).

Buglossoides purpurocaerulea (L.) I. M. Johnston - Meszes: Jóna-hegy, erdőszélen (VA, 1996) [7590.2]; Debréte: Pagony, cseres-tölgyesben (FT, 2001) [7491.3]. MFA online: Tornabarakony (VA, 2004), Büttös (HK, 2004). A Cserehátból kevés adata van.

Calamintha menthifolia Host - Meszes: Vasbánya déli, meredek sziklás oldala (VA, 2020) [7590.4]; Rakacaszend: Gerenda-vigyor (VA, 2020) [7591.1]. MFA online: Tornabarakony (VA, 2004); Büttös (HK, 2004). Az Északi-Cserehátban ritka.

Callitriche palustris L. - Pamlény: Alsó-erdő, forrásláp (FT, FR, 2011) [7591.1]. Irod.: A Rakaca-völgyből és a tornaszentjakabi Szirákó-völgyből ismert (ENDES et al. 2003a). MFA online: Perecse (VV, 2004), Tornaszentjakab (VV, SZF, 2004). Az egész Cserehátban adathiányos faj.

Campanula rapunculus L. - Debréte: Nyírjes (VA, 1996) [7591.1]. MFA online: Tornabarakony (VA, 2004). Cserehát északi területein csak ez az egy korábbi adat van. 
Campanula sibirica L. - Rakaca: Király-hegy északnyugati oldala (VA, MZ, 1996) [7591.1]. Irod.: Hidvégardó: Szent János-hegy (PENKSZA 1998), Rakaca (PEnKSZA 1998), Budai J. adatát közli Soó et al. (1943). Meszes: Jóna-hegy (VoJTKó \& MARSCHALl 1997). Herb.: Rakacaszend: Király-hegy Jakucs és Ér (1952, DE), Rakaca: Fürcs Siroki (1982, DE). MFA online: Becskeháza (SZF, VV, 2003) és Tornaszentjakab (VV, SZF, 2004), Tornabarakony (VA, 2004), Hidvégardó (VV, 2004); Rakaca (név nélkül: 2004).

Cardamine bulbifera (L.) Crantz - Viszló: Barveny-hegy (VA, 1996) [7491.3]; Debréte: temető-oldal (FT, 2001) [7491.3]; Rakaca: Király-hegy északnyugati oldala (VA, MZ, 1996) [7591.1]. Irod.: Tornaszentjakabról (VojtKó \& MARSCHALl 1997). Herb.: Rakacaszend: „Nagykopasztető" gyűjtötte Jakucs és Ér (1952, BP). MFA online: Becskeháza (SZF, VV, 2003) és Tornaszentjakab (VV, SZF, 2004), Tornabarakony (VA, 2004).

Cardamine pratensis L. - Debréte: Nyírjes (VA, 1996 BP) [7591.1] (A herbáriumi lapon Viszló szerepel.); Tornaszentjakab: Sas-patak völgye (VA, PK 1996 BP) [7491.3]; Viszló: Bogolyvölgy (FT, 2000) [7591.1]; Pamlény: Bogoly-völgy (VA, 1996) [7491.4]. Irod.: THAISz (1937) Bódvalenke, Komjáti; Endes et al. (2003a) és Endes (2003b): Rakaca: Proszniszkó-völgy, Rakacaszend: Debréte-patak, Szászfa: Janka-patak és Nagy-rét, Szemere: Som-kúti-völgy, Tornaszentjakab: Szirákó-völgy. MFA online: Az Északi-Cserehát természetes növényzettel rendelkező patakvölgyeiben és a Bódva-völgy jobb állapotú nedves gyepjeiben mindenhol előfordul, gyakori.

Carduus collinus Waldst. et Kit. - Rakaca: Verskó-halom (VA, 1996) [7591.3]. Irod.: Budai rakacaszendi adatát Soó et al. (1943) közli. A Rakaca-patakot követő sziklagyepekből FARKAS J. (1996), Rakacaszend és Rakaca közötti gyepekből PENKSZA \& SALAMON (1997a), Rakacáról és Meszesről (MolnÁr Cs. et al. 2018) írja. A meszesi Jóna-hegyről is ismert (VoJTKó \& MARSCHALl 1997). MFA online: Tornaszentjakab (VV, SZF, 2004). Az egész Cserehátban ritka.

Carex buekii Wimm. - Viszló: Szirákó-völgyben magassásosban (FT, 2009) [7491.3]. Irod.: A Rakaca-völgyben és oldalvölgyeiben több helyen előfordul pl. Büttös: Bakonyi-völgy; Debréte és Rakacaszend: Debréte-patak-völgye; Pamlény: Janka-patak-völgye, Csonkás-völgy, Keresztétei-patak-völgye, Rakaca-völgy; Szászfa; Szemere (EnDES et al. 2003a,b), Tornabarakonyból Endes (2003b), Bódvalenkéről és Perecséről PENKSZA \& SALAMON (1997a) jelzi. MFA online: Hidvégardó (VV, 2004). Az Északi-Cserehátban és a Felső-Bódva-völgyben ritka.

Carex elata All. - Debréte: Alsó-legelő magassásosban (FT, 2000) [7591.1]; Büttös: Rakacavölgy (VA, 1996) [7592.1]. Irod.: Büttös (JAKUCS 1952); Büttös: Bakonyi-völgy, Debréte: Debréte-patak-völgye, Gagybátor, Keresztéte, Meszes, Pamlény, Rakaca, Rakacaszend, Tornaszentjakab, Tornabarakony, Viszló, (ENDES 2003b, ENDES et al. (2003a,b); Szemere (ENDES 2003b, NAGY \& PAPP 1996). MFA online: Tornaszentjakab (VV, SZF, 2004), Becskeháza (SZF, VV, 2003), Perecse (VV, 2004). Az Északi-Cserehát jó állapotú patakkísérő magassásosaiban több helyen előfordul, de adathiányos. A Felső-Bódva-völgyből nincs is adata.

Carex hartmanii Cajander - Pamlény: Janka-patak völgye, magassásosban (FT, 2000) [7591.2]; Viszló: Bogoly-völgy (FT, 2000) [7591.1]. Irod.: Korábbi adatai Pamlény: Bagolyvölgy, Keleti-kert és Tuskós (PENKSzA \& SALAMon 1997a), Pamlény: Csonkás-völgy, Szemere: Rakaca-völgy (ENDES et al. 2003a), Pamlény, Hidvégardó és Tornaszentjakab (FARKAS S. 1999). MFA online: Az Északi-Cserehátban és a Felső-Bódva-völgyben ritka.

Carex montana L. - Debréte: Nyírjes (VA, 1996), Tó-völgy (FT, 2020) [7591.1]; Viszló: Petenye-oldal, cseres tölgyesben (FT, 2001) [7491.3]. MFA online: Tornabarakony és Meszes (VA, 2004). A kvadrátokra új adat. A Tornai-karszttal ellentétben az egész Cserehátból kevésbé ismert. 
Carex remota L. - Pamlény: Bogoly-völgy, égeres alatt (FT, 2009) [7491.3]. MFA online: Szemere (FR, 2004), Tornabarakony (VA, 2004). A faj a Cserehátban ritka. Az itt jelzett előfordulás a flóratérképezési kvadrátra új.

Centaurea jacea subsp. macroptilon (Borbás) Hayek - Viszló: Bogoly-völgy, mocsárréten (FT, 2009) [7591.1]. MFA online: Becskeháza (SZF, VV, 2003) és Tornaszentjakab (VV, SZF, 2004).

Cephalanthera damassonium (Mill.) Druce - Debréte: Temető-oldal (FT, 2020) [7591.1]. Irod:: Magyarország Orchideáinak Atlaszában csak a környező négyzetekben szerepel (MolnÁR V. A. 2011). MFA online: Tornabarakony (VA, 2004).

Cerasus fruticosa (Pall.) Woronow - Debréte: Nagy-kötél (FT, 2000) [7591.1]; Viszló: Fáslegelő (FT, 2009) [7591.1]; Rakaca: Verskó-halom (VA, 1996) [7591.3]. Irod.: EnDEs (1996) és VojTKó \& MARSCHALL (1997) a meszesi Jóna-hegyről írja, valamint utóbbi szerzők Viszló: Vigyor-ból. Rakaca határából (MoLnÁR Cs. et al. 2018) jelzi. Herb.: Budai J. gyűjtése Rakacaszend mellől való (1909, BP) és ezt az adatot hivatkozza (Soó et al. 1943). A Cserehátban ritka.

Chamaecytisus albus (Hacq.) Rothm. - Rakaca: Király-hegy északnyugati oldala (VA, MZ, 1996) [7591.1]. Irod.: Bódvalenke (THAISz 1937); Thaisz adatát hivatkozza JAKUCS (1951); Meszes: Jóna-hegy (VojtKó \& MARSCHALl 1997); Viszló (FARKAS T. 2011) Herb.: Rakaca és Rakacaszendről gyűjtötte Budai (1909, BP) valamint Bódvalenke: Bódva-völgyből Thaisz (1909, BP). Az Északi-Cserehátban ritka.

Chamaecytisus triflorus (Lam.) Skalická - Viszló: Fás-legelő és Dobre-hát rétjein, erdőszélen (FT, 2009) [7591.1], valamint Pamlény: Nyugati-kert alja, fiatal cseres-tölgyes telepítés szegélyében (FT, 2020) [7591.2]. Irod:: Korábban Chamaecytisus hirsutus néven Debréte: Nyírjes dűlőből jelzik (VojTKó \& MARSCHALL 1997).

Chamaenerion angustifolium (L.) Scop. - Viszló: Barveny-hegy (VA, 1996) [7491.3]; Tornaszentjakab: Kanyiszló-völgy (FT, 2009) [7491.3], a Katalin-majortól északra eső erdőtömb (VA, 1996) [7491.3]. Irod.: Tornaszentjakab: Szirákó völgyből és Szemere mellől közlik (ENDES et al. 2003a, ENDES 2003b), valamint Bódvalenkéről THAISZ (1937). MFA online: Becskeháza (SZF, VV, 2003) és Tornaszentjakab (VV, SZF, 2004), Tornabarakony (VA, 2004).

Cirsium ×tataricum DC. /C. canum $\times$ C. oleraceum/ - Szemere: Rakaca-völgy, magaskórósban (FT, FR, 2011) [7592.2]. A Cserehátra új faj.

Cirsium oleraceum (L.) Scop. - Szemere: Rakaca-völgy, magaskórósban (FT, FR, 2011) [7592.2]. Irod.: Korábban csak a Szirákó-völgyből volt adata (ENDEs et al. 2003a, ENDES $2003 b$ ), valamint Bódvalenkéről (PENKSZA \& MALATINSZKY 2010). MFA online: Tornaszentjakab (VV, SZF, 2004), Rakaca (név nélkül: 2004).

Cirsium pannonicum (L.f.) Link - Debréte: Nagy-kötél, félszáraz gyepekben (FT, 2000) [7591.1]. MFA online: Tornabarakony (VA, 2004). A területről irodalmi és herbáriumi adat nem ismert, valamint a megjelölt KEF kvadrátból nem volt előfordulása.

Cnidium dubium (Schkuhr) Thell. - Tornaszentjakab: Szirákó-völgy mocsárrétjében (FT, 2009) [7491.3]. Irod.: Rakaca: Szent István-völgy (VIRóK et al. 2011) és Rakaca-völgy (ENDES et al. 2003a, ENDES 2003b). Az Északi-Cserehátban sok helyen előfordul.

Convallaria majalis L. - Debréte: Temető-oldal (FT, 2000) [7591.1]; Viszló: Ubocs (FT, 2009) [7591.1]; Meszes: Jóna-hegy nyugati lejtő (VA, 1996) [7590.4]. MFA online: Tornabarakony (VA, 2004), Tornaszentjakab (VV, SZF, 2004), Perecse (VV, 2004) és Rakaca (név nélkül: 2004). Tölgyesekben, szórványos.

Cynosurus cristatus L. - Viszló: Fás-legelo, Ubocs rétjein (FT, 2009) [7591.1]; Tornaszentjakab: Bodolai-erdő (VA, 1996) [7491.4]. Irod.: Legközelebbi adata Szemere több pontján van (NAGY \& PAPP 1996), valamint Rakacaszend: Rakaca-völgy (ENDES et al. 2003). MFA online: 
Tornaszentjakab (VV, SZF, 2004). Viszlóról eddig nem jelezték. A Cserehátban ritka, a flóratérképezési kvadrátra új.

Cyperus fuscus L. - Pamlény: Alsó-erdő, forrásláp (FT, FR, 2011) [7591.1], Topolyka-hegy dűlő közepén futó völgyben, amely valójában a Csonkás-völgy oldalvölgye, a forráskifolyónál (FT, 2020) [7491.4]. Irod.: Korábban Rakacaszend: Debréte-patak mellől közölték (ENDEs et al. 2003a). MFA online: Perecse és Hidvégardó (VV, 2004, 2005).

Cystopteris fragilis (L.) Bernh. - Meszes: Vasbánya déli, meredek sziklás oldala (VA, 1996) [7590.4]; Rakaca: Király-hegy északnyugati oldala (VA, MZ, 1996) [7591.1]. Irod.: Rakaca: Király-hegy, herbáriumi hivatkozás (SzERDAHELYI 2009). Herb.: Rakaca: Király-hegy Jakucs (1952, BP). MFA online: Tornabarakony és Tornaszentandrás (VA, 2004) és Szemere (FR, 2004). A terület sziklalakó páfrányokban szegény, hiszen hiányoznak a sziklaalakzatok. Ez alól talán csak a Rakaca-völgy kivétel. A fajt Meszes határából nem jelezték eddig.

Dactylorhiza incarnata (L.) Soó - Pamlény: Janka-patak völgye, mocsárréten (FT, 2009) [7591.2]; Tornaszentjakab: Sas-patak völgye, lápréten (FT, 2009) [7491.3]. Irod.: A Rakacavölgyben a Viszlói-patak mentén, Tornabarakony (ENDES et al. 2003a) és Bódvalenke mellett ismert (PENKSZA \& MALATINSZKY 2010). Az Északi-Cserehátban számos kvadrátból jelzik (MolNÁR V. 2011).

Danthonia alpina Vest - Viszló: Dobre-hát és Fás-legelö (FT, 2009) [7591.1]. Cynosorus cristatus-szal együtt fordul elő, sovány hegyi réten. Irod.: NAGY \& PAPP (1996) csak Szemere mellől írja. A flóraatlasz nem közöl északi-csereháti adatot.

Dianthus armeria L. - Tornaszentjakab: Bodolai-sarok és Bodolai-erdő, erdőszélen (VA, 1996) [7491.4]. Viszló: Felső-rét száraz gyepjében (FT, 2020) [7591.1]. Irod.: THAISz (1937) Bódvalenkéről közli. Herb.: Jakucs Rakacaszend és Meszes között gyűjti a Nagykopasz-tetőn (1952, BP). MFA online: Tornabarakony (VA, 2004), Tornaszentjakab (VV, SZF, 2004, VV, 2005), Perecse (VV, 2004), Büttös (FR, 2004), Tornabarakony (VA, 2004).

Dianthus deltoides L. - Debréte: Nyírjes, erdőszélen (VA, 1996, FT, 2020), Nagy-kötél (FT, 2020) [7591.1]; Pamlény: Alsó-erdő, forrásláp (FT, FR, 2011) [7591.1], Nyugati-kert-alja (FT, 2020) [7591.2], Topolyka-hegy (FT, 2020) [7491.4], Csonkás-oldal (FT, 2020) [7491.2]; Viszló: Szendi-úti-dűlő, Ubocs és Cseresi-földek (FT, 2009) [7591.1], Kúton felüli táblák (FT, 2020) [7491.3], Cseres (VA, 1996) [7591.1]. Irod.: Rakaca: Szent István-völgy, Rakacaszend: Debréte-patak völgye, Pamlény: Janka-patak, Szászfa, Szemere, Tornaszentjakab, Viszló: Viszlói-patak és Meszes (ENDEs et al. 2003a), Szemere (NAGY \& PAPP 1996), Bódvalenke (PenksZa \& MALATINSZKY 2010). MFA online: Tornabarakony (VA, 2004), Tornaszentjakab és Hidvégardó (VV, SZF, 2004, VV, 2004, 2005), Perecse (VV, 2004), Szemere (FR, 2004), Tornabarakony (VA, 2004). Az Északi-Cserehátban viszonylag gyakori növény.

Dictamnus albus L. - Rakaca: Verskó-halom (VA, 1996) [7591.3]. Irod.: Rakaca és Rakacaszend között Budai József találja először 1914-ben. Rakacáról és Rakacaszendről 1957-ben közli adatát FEKETE \& JAKUCS (1957), majd FARKAS J. (1996) a Rakaca-völgyből és a meszesi Jóna-hegyről írja le. Rakacán (MoLnÁR Cs. et al. 2018) is megtalálta. Herb.: Rakacán Siroki gyűjti „füves hegyoldalon” (1982, DE). MFA online: Tornabarakony és Tornaszentandrás (VA, 2001, 2004). A Meszestől Rakacáig futó országút menti sztyeplejtőkön több helyen előfordul. A flóratérképezési négyzetre új adat.

Digitalis grandiflora Miller - Debréte: Nyírjes, a gerincen (VA, 1996) [7591.1], Tó-völgy, cseres-tölgyesben (FT, 2020) [7591.1.]; Rakaca: Király-hegy északnyugati oldala (VA, MZ, 1996) [7591.1]. MFA online: Meszes, Tornabarakony (VA, 2004), Tornaszentjakab és Hidvégardó (VV, SZF, 2004, VV, 2004). A Cserehátban kevés adata ismert. A kvadrátra új előfordulás.

Dryopteris carthusiana (Vill.) H. P. Fuchs - Büttös: Rakaca-völgy (VA, 1996, BP) [7592.1]; Viszló: Barveny-hegy (VA, 1996) [7491.3]; Perecse: Felső-erdő, Koncom (VA, 1996) [7491.4], Ubocs (FT, 2000) [7591.1]; Szemere: Som-kúti-völgy (VA, 1996) [7592.1]; Torna- 
szentjakab: Sas-patak-völgye (VA, 1996 BP) [7491.3], Bodolai-erdő (VA, 1996) [7491.4], Sima-bérc (FT, 2020) [7491.3]. Irod.: Viszlóról Vojtkó adatát közli SzERDAHELYI (2009) a Barveny-hegyről, de ENDES et al. (2003a) Kányról, Meszesről. Szemere: Som-kúti-völgyből, Tornabarakonyból, Tornaszentjakab: Szirákó-völgyből, valamint NAGY \& PAPP (1996) Rakaca-völgyből is írják. MFA online: Az Északi-Cserehát mezofil erdeiben nem ritka.

Dryopteris filix-mas (L.) Schott - Tornaszentjakab: Bodolai erdő (VA, 1996) [7491.4], Debréte-völgy, az út menti vegyes erdő alatt és Sima bérc alatti ligeterdőben (FT, 2020) [7491.3]; Meszes: Nagy-Somos-hegy (VA, 1996) [7590.4]; Viszló: Petenye-oldal, cseres tölgyesben (FT, 2001), Dobre-hát (FT, 2020) [7591.1] vegyeslombú erdő alatt; Debréte: Tóvölgy (FT, 2020) [7591.1] cseres-tölgyesben; Rakaca: Király-hegy északnyugati oldala (VA, MZ, 1996) [7591.1]. Irod.: A területről ENDES et al. (2003a) közöl előfordulásokat Tornaszentjakab: Szirákó-völgyből, Viszlói-patak-völgyéből, Tornabarakony: Barakonyi-völgyből, Rakacaszendről, Szemeréről és Meszes: Rakaca-patak partjáról. A Felső-Bódva-völgyben Bódvalenkén THAISz (1937) közli. MFA online: A flóraatlaszban a terület szinte minden négyzetére írják.

Echium maculatum L. - Rakaca: Verskó-halom (VA, 1996) [7591.3]. Irod.: A Rakaca-völgy száraz gyepeiben FARKAS J. (1996) írja és a Rakaca és Rakacaszend közötti gyepekben PENKSZA \& SAlAmon (1997a) is megtalálja. A meszesi Jóna-hegyről jelezték még (VojtKó \& MARSCHALL 1997). Herb.: Rakacáról konkrét földrajzi név nélkül gyüjtötte Budai J. (1909, BP). MFA online: Tornabarakony (VA, 2004).

Eriophorum angustifolium Honckeny - Viszló: Bogoly-völgy (FT, 2000) [7591.1]; Büttös: Rakaca-völgy (VA, 1996 BP) [7592.1]. Irod.: Korábban előfordult Tornaszentjakab: Szirákóvölgyben, Pamlény: Janka-patak völgyében (ENDES et al. 2003a) és Szemerénél (NAGY \& PAPP 1996). MFA online: Tornaszentjakab (VV, SZF, 2003), Becskeháza (SZF, VV, 2003). A flóratérképezési kvadrátokra új előfordulás. Viszlóról eddig nem volt ismert.

Euphorbia exigua L. - Viszló: Vigyor, szántón (FT, 2009) [7591.1]. Herb.: Jakucs Büttös és Litka között gyűjtötte (1913, BP). MFA online: Hidvégardó, Tornaszentjakab (VV, SZF, 2004), Becskeháza (SZF, VV, 2003), Perecse (VV, 2004).

Filago lutescens L. - Viszló: Vigyor, szántón (FT, 2009) [7591.1]. Herb.: Büttös és Litka között gyűjtötte Jakucs (1953, BP). Irodalmi adat a területról nem ismert.

Fritillaria meleagris L. - Bódvalenke: Kotra (VA, 1996) [7490.4]; Büttös: Rakaca-völgy (VA, 1996) [7592.1]; Viszló: Bogoly-völgy (FT, 2000) [7461.4]. Irod.: Bódvalenke: Kotra dűlőről csak később közlik 2000-2001 közötti adatként (PENKSZA \& MALATINSZKY 2010). A Rakacavölgyből és oldalvölgyeiből számos előfordulását közölték: Büttös: Barakonyi-völgy, Pamlény: Janka-patak völgye, Rakaca, Rakacaszend, Tornabarakony, Tornaszentjakab, Szászfa, Szemere (FARKAS J. 1996, NAGY \& PAPP 1996, VojtKó \& MARSCHALL 1997, ENDES et al. 2003a, ENDES 2003b, PAPP \& NAGY 2003). Szászfa mellől MolnáR Cs et al. (2018) is írja. FelsőBódva-völgyből Komjáti: Szilasi-rétről (VIRóK et al. 2016) jelzik. Herb.: Szászfa és Rakaca között Pócs (1953, BP) és Jakucs (1952 és 1953, BP) gyüjtése ismert. MFA online: Tornaszentjakab (VV, SZF, 2004), Becskeháza (SZF, VV, 2003).

Galeopsis ladanum L. - Tornaszentjakab: Tégla-fej, szántón (FT, 2009) [7491.3]. MFA online: Hidvégardó és Perecse (VV, 2004), Büttös (FR, 2004). A négyzetre új adat.

Galium boreale L. - Tornaszentjakab: Kanyiszló-tető alja kiszáradó lápréten (FT, 2020) [7491.3]. Irod:: Tornaszentjakabról a Szirákó-völgyből, Keresztétéről, Pamlény: Janka-patak mellől, Rakacaszend: Debréte-patak völgyéből, Szemeréről, és Tornaszentjakabról ENDES et al. (2003a) közli. MFA online: Tornaszentjakab (VV, SZF, 2004), Becskeháza (SZF, VV, 2003), Tornabarakony (VA, 2004). A vizsgálati terület kvadrátjainak 2/3-ából írják.

Galium odoratum (L.) Scop. - Viszló: Barveny-hegy (VA, 1996) [7491.3]; Bódvalenke: Kőszög (FT, 1998) [7490.4]. MFA online: Tornaszentjakab (VV, SZF, 2004), Szemere (FR, 
2004), Tornabarakony (VA, 2004). Cseres- és gyertyános-tölgyesekben több helyen előfordul a térségben.

Genista germanica L. - Szemere: Pipiske, legelőerdőben (VA, 1996) [7592.2]; Viszló: Vigyor (VA, 1996 BP), Cseres (VA, 1996) [7591.1]. Irod.: A Cserehátban eddig Debrétéről ismert (VOJTKó \& MARSCHALL 1997).

Genista pilosa L. - Viszló: Kúton felüli-táblák, erdőszélen (FT, 2000) [7491.3]. MFA online: Tornabarakony (VA, 2004). A Cserehátban adathiányos faj.

Genista tinctoria L. - Pamlény: Topolyka-hegy (FT, 2009) [7491.4]; Viszló: Cseresi-földek és Fás-legelő (FT, 2009) [7591.1]; Tornaszentjakab: Herceg-tető (FT, 2020) [7491.3]. Irod.: MoLNÁR Cs. et al. (2016) a Bódva-völgy távolabbi részéről, Szendrő mellől közli. MFA online: Perecse (VV, 2004), Tornaszentjakab (VV, 2005), Büttös (FR, 2004), Tornabarakony (VA, 2004).

Gentiana cruciata L. - Viszló: Partos-földek és Fás-legelő (FT, 2000), Cseres (VA, 1996) [7591.1]; Tornaszentjakab: Viszlói-oldal, és Tégla-lápa (FT, 2000), Suta-völgy (FT, 2020) [7491.3]. Irod.: Korábban FARKAS T. (2011) már jelzi a területről a Sas-patak mellől, és Viszló: Partos-földek, Fás-legelő és Barveny-hegyről, valamint VojTKó \& MARSCHALl (1997) Debrétéről. További adatai vannak a Rakaca-völgyből Rakaca: Proszniszkói-völgy, Rakacaszend: Éger-völgy (FARKAS J. 1996) és Rakaca: Lucernás és Szendi-oldal. (MoLNÁR Cs. et al. 2018) megjelöléssel. MFA online: Tornaszentjakab (VV, SZF, 2004).

Geranium palustre L. - Szemere: Szőlők-alatti-völgy láprétjén (VA, 1996) [7592.2]. Irod.: A Rakaca-völgyből (Rakaca, Rakacaszend, Szemere) Gagybátorból és Viszló: Viszlói-patak mellől (NAGY \& PAPP 1996, ENDES et al. 2003a) és Szemeréről (FARKAS J. 1996) ismert. A Felső-Bódva-völgyben Bódvalenke: Kotra (VIRóK et al. 2016). MFA online: Tornabarakony (VA, 2004).

Geranium pratense L. - Szemere: Szőlők-alatti-völgy, láprét szélén, valamint Rakaca-völgy (VA, PK 1996) [7592.2]; Alsógagy: Vasonca, árokparton (FT, 2018) [7692.1]; Büttös: Rakaca-völgy (VA, 1996) [7592.1]. Irod.: A vizsgált területről a Rakaca-völgyből (Szemere, Rakaca) (ENDES et al. 2003a) és Hidvégardóból (VojTKó 2008) ismert irodalmi adata. MFA online: Szászfa (név nélkül: 2004), Büttös (HK, FR, 2004). A Cserehát keleti részén, a Hernádvölgyben és az Északi-Zemplénben gyakori, máshol ritka.

Geranium sanguineum L. - Meszes: Jóna-hegy, sztyepréten (VA, 1996) [7590.2]. Irod.: A Jóna-hegyről eddig nem közölték, csak Büttösről (ENDES at al. 2003a), Hidvégardó: Szent János-hegyről (PENKSZA 1998) és Rakacáról (MoLNÁR et al. 2018) van adata. MFA online: Tornaszentjakab (VV, SZF, 2004), Becskeháza (SZF, VV, 2003).

Glyceria maxima (Hartman) Holmberg - Viszló: Bogoly-völgy, Alsó-rét (FT, 2009) [7591.1]; Tornaszentjakab: Sas-patak-völgye (FT, 2020) [7491.3]; Pamlény: Janka-patak-völgye (FT, 2001) [7591.2], Bogoly-völgy (FT, 2020) [7491.4]. Irod.: Legközelebb a Büttös: Bakonyivölgyből, Rakaca: Rakaca-völgyből, Rakacaszend: Debréte-patak völgyéből, Viszló: Viszlóipatak mellől, Gagybátor: Bátor-patak mellől és Kányból van ismert előfordulása (ENDES et al. 2003a). MFA online: Tornaszentjakab (VV, SZF, 2004), Becskeháza (SZF, VV, 2003), Büttös (HK, 2004), Szászfa (név nélkül: 2004), Tornabarakony (VA, 2004).

Holcus lanatus L. - Debréte: Nagy-kötél (FT, 2009) [7591.1]; Pamlény: Topolyka-hegy (FT, 2009) [7491.4]; Viszló: Alsó-rét (FT, 2000) [7591.1]; Tornaszentjakab: Tégla lába (FT, 2009) [7491.3]; Hidvégardó: Alsó-rét (FT, VA, 2020) [7490.4]. Irod.: Keresztéte; Kány; Rakaca: Priszniszkói-völgy, Rakaca-völgy; Rakacaszend: Debréte-patak, Meszes és Szemere: Rakaca-völgy; Viszló: Viszlói-patak; Pamlény: Janka-patak; Tornabarakony (EnDES et al. 2003a, NAGY \& PAPP 1992, 2003). MFA online: Tornaszentjakab (VV, SZF, 2004), Becskeháza (SZF, VV, 2003), Büttös (HK, 2004). Az Északi-Cserehátban adathiányos faj, ugyanakkor jobb állapotú nedves gyepekben, hegyi réteken sok helyen előfordul. 
Inula ensifolia L. - Viszló: Szendi-úti-dűlő (FT, 2009) [7591.1]; Tornaszentjakab: Szirákóvölgy és Kanyiszló-tető (FT, 2009) [7491.3]. Irod.: Büttös: Bakonyi-völgy, Szemere: Rakacavölgyből (ENDES et al. 2003a). MFA online: Tornaszentjakab (VV, SZF, 2004), Becskeháza (SZF, VV, 2003), Perecse (VV, 2004), Rakaca (név nélkül: 2004), Tornabarakony (VA, 2004).

Iris pseudacorus L. - Büttös: Rakaca-völgy (VA, 1996) [7592.1]; Pamlény: Bogoly-völgy (FT, 2001) [7491.4]; Tornaszentjakab: Kanyiszló-völgy (FT, 2009) [7491.3]. Irod.: Büttösről JAKuCS (1952) közli, földrajzi név nélkül. Debréte, Kány, Keresztéte, Pamlény, Rakaca, Rakacaszend, Szászfa, Szemere, Tornabarakony, Tornaszentjakab községhatárokból is ismert (ENDES et al. 2003a). Szemere melleti kutatásai során NAGY \& PAPP $(1996,2003)$ is rábukkant. A Felső-Bódva-völgyből Bódvalenkéről THAISz (1937) írja. MFA online: Cserehátban gyakori.

Iris sibirica L. - Szemere: Szőlők-alatti-völgy, lápréten (VA, 1996) [7592.2]; Viszló: Bogolyvölgy (FT, 2000), Szászi-völgy (VA, 1996) [7591.1]. Irod.: A Rakaca-völgyben és oldalvölgyeiben szinte minden településről közlik: Gagybátor, Litka, Keresztéte, Rakaca, Rakacaszend, Szászfa, Szemere, Tornabarakony, Tornaszentjakab (ENDES et al. 2003a, NAGY \& PAPP 1992, 1996, 2003). FARKAS J. (1996) Kányból, VojTKó (2008) a Juhász-patak völgyéből írja Becskeháza határában, Molnár Cs. et al. (2018) Szászfa mellől közli. A Felső-Bódvavölgyben Bódvalenke mellől van irodalmi adata (PENKSZA \& MALATINSZKY 2010). MFA online: Tornaszentjakab (VV, SZF, 2004), Becskeháza (SZF, VV, 2004), Perecse (VV, 2004). Az Északi-Cserehát jobb állapotú patakvölgyeiben szinte minden lápréten előfordul.

Lathyrus nissolia L. - Meszes: Jóna-hegy (VA, 1996 BP) [7590.2]. Irod.: Pamlény: Nagykötélről közli ViróK et al. (2011), MoLnÁr Cs. et al. (2018) pedig Tornaszentjakabról. Komjátiból SomLYAY (2000) írja. MFA online: Az Északi-Cserehátból kevés adata ismert. A négyzetre új adat.

Lembotropis nigricans (L.) Griseb. - Viszló: Ubocs, mészkerülő tölgyes szegélyében (FT, 2020) [7591.1]. MFA online: Tornabarakony (VA, 2001), Tornaszentjakab (VV, SZF, 2004), Büttös (FR, 2004). Az Északi-Cserehátban elég ritka, a négyzetben eddig nem volt ismert előfordulása.

Lilium martagon L. - Meszes: Nagy-Somos-hegy sziklásabb oldala (VA, 1996) [7590.4]; Viszló: Gyertyános (FT, 2000) [7491.3]; Bódvalenke: Kő-szög (FT,1998) [7490.4). Irod.: Korábban FARKAS T. (2011) közli Tornaszentjakabról. Herb.: Jakucs Rakacaszend: Nagykopasztető „Ördögtorokszakadék” (1952, BP). MFA online: Tornabarakony (VA, 2004). Az egész Cserehátban ritka, vagy adathiányos. A Felső-Bódva-völgy négyzeteiben is szerepel, de azok az adatok nem a völgyre vonatkoznak.

Lycopodium clavatum L. - Viszló: Ubocs, mészkerülő tölgyes foltban (FT, 2000) [7591.1]. Irod.: Tornaszentjakabtól ÉK-re lévő fenyvesből (Madaras) jelzi ENDES (1995b), ENDES \& SzABó (1996) és a Bodolai-erdőből VojTKó \& MARSCHALl (1997). MFA online: Tornaszentjakab (VV, SZF, 2004), Becskeháza (SZF, VV, 2003). Az egész Cserehátban ritka.

Lycopus exaltatus L. f. - Tornaszentjakab: Kanyiszló-völgy (FT, 2009) [7491.3]. Irod.: Szászfa és Szemere: Rakaca-völgy (EndEs et al. 2003a, NAGY \& PAPP 2003). MFA online: Büttös és Szemere (FR, 2004), Tornabarakony (VA, 2004). A négyzetre új előfordulás.

Maianthemum bifolium (L.) F. W. Schmidt - Viszló: Barveny-hegy (VA, 1996) [7491.3]. Irod.: Tornaszentjakab (VoJTKó \& MARSCHALl 1997, ENDES \& SzABó 1996). Herb.: Jakucsnak 1952ből (DE) van herbáriumi lapja Rakacaszend: Nagykopasz-tetőről. MFA online: Tornaszentjakab (VV, SZF, 2004), Becskeháza (SZF, VV, 2003), Perecse (VV, 2004). Viszlóról még nem jelezték korábban.

Melampyrum cristatum L. - Meszes: Jóna-hegy, félszáraz gyepek a dombtetőn (VA, 1996) [7590.2]. MFA online: Tornabarakony (VA, 2004), Tornaszentjakab (VV, SZF, 2004). A Cserehátban ritka. A községhatárból még nem közölték és a négyzetre is új.

Myosotis scorpioides L. - Büttös: Rakaca-völgy (VA, 1996) [7592.1]. Irod.: Büttös: Bakonyivölgyből, Gagybátorból, Meszes, Pamlény, Rakaca, Rakacaszend, Szászfa, Szemere, Torna- 
szentjakab, Viszló községhatárból jelzi EnDEs et al. (2003a), Tornabarakonyból és Debrétéről ENDES $(2003 b)$. Szemere település határában a láprétek kutatása közben feljegyezte NAGY \& PAPP (1992, 1996). A Felső-Bódva-völgyben Bódvalenkéről THAISZ (1937) közli. MFA online: Az Északi-Cserehátban szinte minden négyzetben megtalálható, kivéve 7491.4.

Nardus stricta L. - Büttös: Rakaca-völgy (VA, 1996) [7592.1]. Irod.: PENKSZA \& SALAMON $(1997 a, b)$ Pamlény és Tornaszentjakab mellől írják. MFA online: Az egész Cserehátban nagyon ritka. A négyzetre új adat.

Neottia nidus-avis (L.) L.C.M. Richard - Meszes: Nagy-Somos-hegy sziklásabb oldala (VA, 1996) [7590.4]; Viszló: Gyertyános (FT, 2000) [7491.3]; Bódvalenke: Becskeházi-erdő (FT, 1998) [7490.4]. Irod.: Korábbi adatai a területről Debréte, Tornaszentjakab és Viszló: Cseres (FARKAS T. 2011), valamint az Északi-Cserehát számos pontján (MoLNÁR V. 2011). MFA online: Az Északi-Cserehátban gyakori faj, a Bódva-völgy négyzeteiben lévő adatok valószínűleg a környező hegyoldalakra vonatkoznak.

Orchis morio L. - Viszló: Barveny (FT, 2001) [7491.3]; Viszló: Fás-legelő (FT, 2000) [7591.1]; Tornaszentjakab: Viszlói-oldal (FT, 2000) [7491.3]; Meszes: Cseres (VA, 1996) [7590.4]. Irod.: ENDES \& SzABó (1996) valamint EndES (1997) Tornabarakony: Madarasról és a Barakonyi-patak mellől írja le különleges színváltozatát, valamint Tornaszentjakab: Szirákó völgyből jelzik (ENDES et al. 2003a). MoLNÁR V. (2011) az Északi-Cserehátban minden négyzetben írja. Szerzők korábbi munkáiban több egyéb Viszló mellőli előfordulást tesznek közzé (FARKAS T. 2011), valamint a meszesi Jóna-hegyről írják (VoJTKó \& MARSCHAL 1997). MFA online: Az Északi-Cserehátban gyakori faj.

Ornithogalum umbellatum L. s.l. - Debréte: Debréte-patak-völgye, mocsárrét szélén (FT, 2020) [7591.1]. Irod.: A Cserehát ezen részén Rakacaszendről közlik (ENDES et al. 2003a). Herb.: Rakacaszend Jakucs (1952, DE). MFA online: Meszes (VA, 2004).

Parthenocissus inserta (A. Kern.) Fritsch - Tornaszentjakab: Sas-patak-völgye, Szirákóvölgy (FT, 2020) [7491.3]; Viszló: Felső-rét, Bogoly-völgy (FT, 2020) [7591.1]. MFA online: Tornabarakony (VA, 2004). Patakvölgyekben, útszéleken terjedőben.

Persicaria bistorta (L.) Samp. - Büttös: Rakaca-völgy (VA, 1996) [7592.1]; Viszló: Bogolyvölgy (FT, 2000) [7591.1], Szirákó-völgy (FT, 2009) [7491.3]; Tornaszentjakab: Kanyiszlóvölgy (FT, 2020) [7491.3]. Irod.: Debréte: Barakonyi-patak mellől, Litka, Pamlény, Rakaca, Rakacaszend, Szászfa, Szemere, Tornabarakony, Tornaszentjakab településekről vannak adatai (ENDES 2003b, ENDES et al. 2003a). Szemerén NAGY \& PAPP $(1992,1996,2003)$ is jelzi. Tornaszentjakab: Sas-patak-völgyéből FARKAS J. (1996) is írja. VojTKó (2008) a Kány határában található Homolya égereséből közli és ezt az adatot találjuk VIRóK \& FARKAS R. 2007es cikkében is. MoLnÁR Cs. et al. (2018) Szászfa mellől közlik. Bódvalenkéről PENKSZA \& MALATINSZKY (2010) írja előfordulását. Herb.: Jakucs már megtalálta Büttös és Litka között az ún. Németh-árokban és gyűjtötte is (1952, DE, BP). MFA online: Az Északi-Cserehát patakvölgyeinek láprétjein kisebb-nagyobb egyedszámban sok helyen él. A Bogoly-völgyből korábban nem közölték.

Platanthera bifolia (L.) - Meszes: Vasbánya (VA, 1996) [7590.4]; Pamlény: Alsó-erdő (FT, 2000) [7591.1], Bogolyi-erdő (FT, 2000) [7491.4]; Viszló: Petenye-oldal (FT, 2001), Köbli (FT, 2020) [7591.1] cseres-tölgyes erdőben. Irod.: FARKAS T. (2011) Debréte, Tornaszentjakab és Viszló mellől, VojTKó \& MARSCHALl (1997) Meszes: Tapolca-hegyről, Tornaszentjakab: Bodolai erdőből és Viszló: Vigyorból, ENDES \& SzABó (1996) Tornaszentjakab: Madarasról közli. Az Északi-Cserehát minden négyzetében előfordul (MoLnÁR V. 2011).

Polygala comosa Schkur. - Szakácsi: Felső-dedella (VA, 2004 BP) [7691.1]; Debréte: Vastagerdő (FT, 2020) [7591.1]. Irod.: Rakacaszend és Tornaszentjakab községhatárból közli ENDES et al. (2003a). MFA online: Tornaszentjakab (VV, SZF, 2004), Becskeháza (SZF, VV, 2003). 
Polygala major Jacq. - Pamlény: Kúton-felüli-dűlő (FT, 2000) [7491.3]; Tornaszentjakab Viszlói-oldal (FT, 2000) [7491.3]. Irod.: Korábban Pamlény: Bogoly-völgy és Tornaszentjakab Szirákó-völgyből és Suta-völgyből (FARKAS T. 2011) Meszesről a Jóna-hegyről és Szemeréről FARKAS J. (1996) valamint Rakacaszendről Budai adatát teszi közzé Soó et al. (1943). Herb.: Rakacaszenden Budai (1909, BP) és Jakucs (1952, DE) gyűjtötte. MFA online: Az Északi-Cserehátban gyakori.

Polygonatum multiflorum (L.) All. - Viszló: Barveny-hegy (VA, 1996) [7491.3]. Irod.: Szerző korábban a tornaszentjakabi Katalin-majorból írja (VoJTKó \& MARSCHALL 1997). MFA online: Tornaszentjakab (VV, SZF, 2004), Becskeháza (SZF, VV, 2003), Perecse (VV, 2004), Szemere (FR, 2004).

Polypodium vulgare L. - Meszes: Nagy-Somos-hegy sziklásabb oldala és Vasbánya déli, meredek sziklás szakasza (VA, 1996) [7590.4]; Rakaca: Király-hegy északnyugati oldala (VA, MZ, 1996) [7591.1]. MFA online: Tornabarakony (VA, 2004), Rakaca (név nélkül: 2004); Tornaszentjakab (VV, SZF, 2004), Becskeháza (SZF, VV, 2003). A Cserehátban ritka.

Primula veris L. - Viszló: Barveny-hegy (VA, 1996), Petenye-oldal, cseres tölgyesben (FT, 2001) [7491.3]; Meszes: Csap-hegy (VA, 1996) [7590.4]. Irod.: Szerzőnek Tornaszentjakab mellől van korábbi adata (VojTKó \& MARSCHALl 1997). Herb.: Rakaca: Király-hegyről ismert Jakucs (1952, BP) gyújtése. MFA online: Tornaszentjakab (VV, SZF, 2004), Becskeháza (SZF, VV, 2003), Perecse (VV, 2004), Büttös (FR, 2004), Tornabarakony (VA, 2004).

Prunella laciniata L. - Pamlény: Nyugati-kertek alja. Fiatal cseres-tölgyes telepítés szegélyében (FT, 2020) [7591.2]. Irod.: A Rakaca-völgyből Szemeréről (NAGY \& PAPP 1996) és Hidvégardóból közölték (MolnÁR Cs. et al. 2018). MFA online: Büttös (HK, 2004), Tornabarakony, Meszes (VA, 2004). A négyzetre új előfordulás.

Pseudolysimachion longifolium (L.) Opiz - Pamlény: Bogoly-völgy (FT, 2009) [7491.3], Közép-domb (FT, 2009) [7591.2]; Szemere: Szőlők-alatti-völgy, lápréten és Rakaca-völgy (VA, 1996) [7592.2]; Bódvalenke Pongrác-féle dűlőben, a Bódvalenkére vezető út menti árokparton (VA, FT, 2020) [7490.4]; Tornaszentjakab: Kanyiszló-völgy (FT, 2009) [7491.3]. Irod.: Kány, Keresztéte, Litka, Meszes, Pamlény: Janka-patak-völgye és a Csonkás-völgy, Rakacaszend, Rakaca, Szászfa, Szemere: Rakaca-völgy, Tornabarakony: Barakonyi patak, Viszló (ENDES et al. 2003a), Debréte (ENDES 2003b). VoJTKó (2008) a Juhász-patak völgyéből írja Becskeháza mellett és Bódvalenkéről a Gedony-rétről. Tornaszentandrásról SoMLYAY (2000) közli, valamint előfordul Bódvalenke: Kapitány-rét; Kotra; Bódvaszilas: Kenderföldek, Ragya; Hidvégardó: Töviskes, Nagy-nyilas; Komjáti: Szilasi-rét, Szokolóczki-féletelek (VIRÓK et al. 2016). Bódvalenkéről már THAISZ 1910-ben és 1937-ben is írja. Herb.: Bódvalenke: Thaisz (1909, BP), Büttös: Jakucs (1953, BP), Bódvaszilas: a MÁV pálya árka mentén, a rákói út elágazása körül (Hulják 1938, DE). MFA online: Tornaszentjakab (VV, SZF, 2004), Rakaca (név nélkül: 2004).

Pteridium aquilinum (L.) Kuhn - Szemere: Rakaca-völgy ligeterdőben (FT, FR, 2011) [7592.2], Pipiske (VA, 1996) [7592.2]; Tornaszentjakab: Fa út környéke (FT, 2020) [7491.2]. Az Északi-Cserehátban irodalmi közlése nincs és a Flóraatlasz sem tartalmaz erre a területre adatot a fajról.

Pulsatilla grandis Werder. - Rakaca: Király-hegy északnyugati oldala (VA, MZ, 1996) [7591.1]. Irod.: Meszes: Jóna-hegy (VojtKó \& MARSCHALl 1997) és Hidvégardó: Szent Jánoshegy (FARKAS J. 1996). Herb.: Rakaca: Király-hegy Jakucs (1952, BP). MFA online: Hídvégardó (VV, 2004); Tornaszentjakab (VV, SZF, 2004).

Pyrola rotundifolia L. - Tornaszentjakab: Hideg-oldal, mészkerülő erdőfoltban (FT, 2000) [7491.3]. Irod.: Eddig Szemeréről és Viszlón az Ubocs-ról ismert előfordulása (ENDES et al. 2003a, PENKSZA \& SALAMON 1997b, FARKAS J. 1996, FARKAS T. 2011). Kány és Szemere határában VIRóK et al. (2011) is közli. MFA online: Perecse (VV, 2004). A Cserehátban ritka. 
Quercus virgiliana (Ten.) Ten. - Meszes: Jóna-hegy (VA, 1996) [7590.2]. Korábbi előfordulási adata nincs a területről.

Ranunculus flammula L. - Tornaszentjakab: Sas-patak-völgye (VA, PK, 1996) [7491.3]. Irod.: Tornaszentjakab: Szirákó-völgyben a tornabarakonyi Barakonyi-völgyben, valamint Szemere: Rakaca-völgyben ismert előfordulása (ENDES et al. 2003a, ENDES 2003b. TAKÁCS et al. 2016). Herb.: Jakucs: Büttös (1933, BP). MFA online: Büttös és Perecse (FR, 2004), Tornaszentjakab (VV, SZF, 2004), Becskeháza (SZF, VV, 2003).

Rosa gallica L. - Debréte: Tó-völgy (FT, 2000) [7591.1]; Viszló: Tó-völgy, Szendi-úti-dűlő, Dobre-hát (FT, 2009), Virágos-kert (FT, 2020), Cseres (VA, 1996) [7591.1]; Tornaszentjakab: Suta-völgy, Szirákó-völgy, Herceg-tető (FT, 2009) [7491.3], Debréte-völgy és Hercegtető (FT, 2020) [7491.3]; Pamlény: Csonkás-oldal (FT, 2020) [7591.2]. Irod.: Debréte mellett a Nagy-Kötélről, Viszlóról a Cseresi-földekről, a Partos-földekről (FARKAS T. 2011), Ubocs és Vigyor dűlőkből és Meszes: Jóna-hegyről (VojTKó \& MARSCHALL 1997), valamint Szemere: Som-kúti-völgyből (ENDES et al. 2003a) ismert. MFA online: Tornaszentjakab (VV, SZF, 2004).

Rosa spinosissima L. - Viszló: Barveny-hegy (FT, 2001) [7491.3]. MFA online: Tornaszentandrás (VA, 2001). Az Északi-Cserehátban és a Felső-Bódva-völgyben eddig nem jelezték.

Sanguisorba officinalis L. - Bódvalenke: Kotra (VA, PK, 1996) [7490.4]; Tornaszentjakab: Sas-patak-völgye (VA, PK, 1996), Kanyiszló-völgy (FT, 2009) [7491.3]; Pamlény: Bogolyvölgy (VA, 1996) [7491.4]; Büttös: Rakaca-völgy (VA, 1996) [7592.1]; Viszló: Dobre-hát (FT, 2020) [7591.1]. Irod.: A faj ismert Büttös: Bakonyi-völgy, Debréte, Gagybátor, Keresztéte, Litka, Meszes, Pamlény: Janka-patak-völgye, Rakaca, Rakacaszend, Szászfa, Tornabarakony: Barakonyi-völgy, Tornaszentjakab: Szirákó-völgy, Viszló: Viszlói-patak-völgye (ENDES et al. 2003b) dűlőkből és Szemeréről is jelzik (NAGY \& PAPP 1996, 2003). FelsőBódva-völgyben: Bódvalenke: Gedony-rét; Kapitány-rét, Grajzinger-rét (VIRóK et al. 2016). MFA online: Az egész Északi-Cserehátban és Bódva-völgyben gyakori.

Scorzonera purpurea L. - Rakaca: Verskó-halom (VA, 1996) [7591.3]. Leközölt irodalmi adata, herbáriumi gyűjtése az egész Cserehátról és Felső-Bódva-völgyből nem ismert.

Scutellaria hastifolia L. - Pamlény: Bogoly-völgy, lápréten (FT, 2009) [7491.4]; Szemere: Szőlők-alatti-völgy, lápréten (VA, 1996) [7592.2]. Irod.: Pamlény mellett a Janka-patak völgyében és Szemerén a Rakaca-völgyben, Rakacaszenden, Szászfán, Tornabarakony: Barakonyi-völgyben találta eddig (ENDES et al. 2003a). MolnÁR Cs. et al. (2018) Rakaca mellől közli. A Felső-Bódva-völgyből Komját mellől írta THAISz (1937). Herb.: Meszesről Budai (1909, BP) gyújtötte. MFA online: Büttös (HK, FR, 2004), Szászfa (név nélkül: 2004), Tornanádaska (VA, 2001), Tornaszentjakab (VV, SZF, 2004).

Serratula tinctoria L. - Tornaszentjakab: Sas-patak-völgye (VA, 1996), Herceg-tető alatt (FT, 2020) [7491.3]. Irod.: A település határából eddig csak a Szirákó-völgyből közölték, valamint Tornabarakony: Barakony-völgyből Büttös: Bakonyi-völgy, Debréte: Debtéte-patak völgye, Gagybátor: Bátor-patak völgye, Kány, Keresztéte, Litka, Pamlény, Rakaca, Rakacaszend, Szászfa, Szemere, Viszló (ENDES et al. 2003b, NAGY \& PAPP 1996, 2003). Bódvalenkéről THAISZ (1937) írja. MFA online: A vizsgálati területen gyakori.

Seseli osseum Crantz em. Simonk. - Viszló: Cseresi-földek, sztyepréten (FT, 2009) [7591.1]; Rakaca: Király-hegy északnyugati oldala (VA, MZ, 1996) [7591.1]. Irod.: PEnKSZA (1998) Hidvégardó: Szent János-hegy. MFA online: Rakaca (név nélkül: 2004), Becskeháza (SZF, VV, 2003). Az Északi-Cserehátból és a Felső-Bódva-völgyből kevés adata ismert.

Silene noctiflora L. - Tornaszentjakab: A Katalin-majortól északra eső erdőtömb (VA, 1996) [7491.3]. Irod.: Meszes (VIRóK et al. 2011.). MFA online: Tornaszentjakab (VV, SZF, 2004), Szemere (FR, 2004). Az Északi-Cserehátban csak szórványos adatai vannak.

Silene nutans L. - Hidvégardó: Ruda-tető (VA, 2001 BP) [7491.3]. MFA online: Büttös és Perecse (FR, 2004). 
Silene viscosa (L.) Pers. - Viszló: Barveny-hegy (VA, 1996) [7491.3]. Irod.: VojTKó \& MARSCHALL (1997) Tornaszentjakabról közli. MFA online: Tornaszentjakab (VV, SZF, 2004), Becskeháza (SZF, VV, 2003), Tornabarakony (VA, 2004).

Solidago gigantea Aiton - Pamlény: Topolyka-hegy (FT, 2009) [7491.4]; Tornaszentjakab: Tégla lába és Herceg-tető (FT, 2009) [7491.3]; Viszló: Kacure (FT, 2009) [7591.1], Köbli (FT, 2020) [7591.1]. Irod.: Korábbi adatai Szemere és Litka mellől (ENDES et al. 2003a), valamint Bódvalenke: Kotra (VIRóK et al. 2011). MFA online: A Rakaca-völgy nagy részéről a Flóraatlaszban nincs adata, csak ettől északra terjedt el. Mint terjedő adventív gyomfaj, terjedését mindenképp nyomon kell követni. Egyre nagyobb területeket borít, főleg felhagyott szántókon és nedves gyepekben terjed a tájegységben.

Sonchus palustris L. - Szemere: Szőlők-alatti-völgy, lápréten (VA, 1996) [7592.2]; Pamlény: Bogoly-völgy (FT, 2009) [7491.4], Közép-domb (FT, 2009) [7591.2]; Bódvalenke: Partosoldali-mocsár (VA, FT, 2020) [7490.4]. Irod.: Korábban BÁNKUTI \& VojTKó (1995) a fajra vonatkozó előfordulásokat közöl Tornaszentjakab Meszes, Alsógagy és Rakaca mellől. VojTKó (2008) a Juhász-patak völgyéből írja Becskeháza mellett, valamint FARKAS T. (2011) a Janka-patak völgyéből. Keresztéte, Szemere községhatárból (ENDES et al. 2003a), csak Szemeréről NAGY \& PAPP $(1996,2003)$ közli. Felső-Bódva-völgyben: Bódvalenke; Komjátitól nyugatra; Komjáti: Csigás; Perkupától délre, az égerszögi elágazásnál; Szalonna: Bakos-dűlő; Szögliget és Bódvarákó között (PENKSZA \& MALATINSZKY 2010). Bódvalenke: Kotra, Kapitányrét; Hidvégardó: Alsó-rét; Töviskes (VIRóK et al. 2016). Valószinűleg terjedőben.

Spiraea media Schmidt - Rakaca: Király-hegy északnyugati oldala (VA, MZ, 1996) [7591.1]. Irod.: Rakacaszendről Tóth E. 1996-os adatát közli FARKAS S. (1999) és BöLÖNI \& NAGY (1999). MFA online: Tornaszentjakab (VV, SZF, 2004). Északi-Cserehátban ritka.

Stachys sylvatica L. - Viszló: Barveny-hegy (VA, 1996) [7491.3]; Pamlény: Bogoly-völgy (FT, 2009) [7491.4]. Irod.: Bódvalenkéről pedig THAISz (1937) közli. Herb.: Rakacaszend és Meszes között Jakucs gyűjtötte a növényt az ún. „Ördögtorokszakadékból” (1952, BP). MFA online: Tornaszentjakab (VV, SZF, 2004), Perecse (VV, 2004), Tornabarakony (VA, 2004).

Succisa pratensis Moench - Pamlény: Topolyka-hegy, mocsárréten (FT, 2009) [7491.4]; Szemere: Szőlők-alatti-völgy, lápréten (VA, 1996) [7592.2]. Irod.: Szemeréről a Rakacavölgyből, Tornabarakonyból vannak korábbi előfordulásai (NAGY \& PAPP 1996). Debréte, Szemere, Tornaszetjakab, Rakaca, Rakacaszend Endes et al. (2003a), míg Szemere és Tornaszentjakab községhatárokból FARKAS J. (1996) is közli. MFA online: Büttös (HK, 2004), Tornaszentjakab (VV, SZF, 2004), Becskeháza (SZF, VV, 2003), Tornaszentandrás és Tornanádaska (VA, 2001). A Cserehátban adathiányos faj.

Thalictrum minus L. - Rakaca: Verskó-halom (VA, PK 1996) [7591.3], Király-hegy északnyugati oldala (VA, MZ, 1996) [7591.1]; Meszes: Csap-hegy VA, 1996) [7590.4]; Rakacaszend: Csonka-erdő (VA, 1996) [7590.4]. Irod.: A fajnak Rakacáról nincs irodalmi közlése és Meszesről csak a Jóna-hegyről van adata (VojTKó \& MARSCHALL 1997). MFA online: Hidvégardó (VV, 2004). A vizsgált területen ritka.

Trifolium montanum L. - Viszló: Vigyor (VA, 1996) és Cseresi-földek (FT, 2009) [7591.1]. Irod.: ENDES et al. (2003b) Kányból, Pamlényről, Rakacáról és Tornaszentjakabról jelzi előfordulását, MoLnÁR Cs. et al. (2018) Rakacáról. MFA online: Perecse (VV, 2004), Tornabarakony (VA, 2004). Az Északi-Cserehátban és a Felső-Bódva-völgyben ritka, vagy adathiányos.

Veronica anagallis-aquatica L. - Viszló: Bogoly-völgy (FT, 2009) [7591.1]; Szalonna: Horgász-part (FT, 2015) [7590.2]. Irod.: Komjáti ThAISz (1937). Herb.: Komjátinál Thaisz gyűjti (1909, BP). MFA online: Perecse (VV, 2004), Büttös (FR, 2004). A flóratérképezési kvadrátra új, egyébként szórványos az Északi-Cserehát patakvölgyeiben és a Felső-Bódvavölgyben. 
Viburnum opulus L. - Viszló: Barveny-hegy (VA, 1996) [7491.3]; Meszes: Nagy-Somos-hegy (VA, 1996) [7590.4]. Irod.: Kány, Keresztéte, Meszes: Rakaca, Rakacaszend, Szemere: Somkúti-völgy, Viszló: Viszlói-patak mellől EnDEs et al. (2003b) jelzi. Felső-Bódva-völgyből Bódvalenkéről THAISZ (1937) közli. MFA online: A vizsgált területen gyakori.

Viola canina L. s.l. - Tornaszentjakab: Sas-patak-völgye (VA, 1996 BP) [7491.3]; Viszló: Vigyor (VA, 1996 BP) [7591.1]. Irod:: Pamlény: Csonkás-völgyben, Rakacaszend: Debrétepataknál, Szemere: Rakaca-völgyben, Viszló: Viszlói-pataknál EnDES et al. (2003a) jelzi. MFA online: Tornaszentjakab (VV, SZF, 2004), Becskeháza (SZF, VV, 2003), Büttös (FR, 2004). A területen ritka.

Viola hirta L. - Viszló: Barveny-hegy; Tornaszentjakab: Petenye-oldal (VA, 1996) [7491.3]. MFA online: Tornaszentjakab (VV, SZF, 2004), Becskeháza (SZF, VV, 2003), Büttös (FR, 2004), Rakaca (név nélkül: 2004).

Viola reichenbachiana Jord. - Viszló: Barveny-hegy (VA, 1996), Tornaszentjakab: Katalinmajor [7491.3]. MFA online: Tornaszentjakab (VV, SZF, 2004), Becskeháza (SZF, VV, 2003), Tornabarakony (VA, 2004). Valószínűleg gyakoribb a területen, de adathiányos faj.

Viola riviniana Rchb. - Viszló: Barveny-hegy (VA, 1996) [7491.3]; Perecse: Felső-erdő (VA, 1996) [7491.4]. Irod.: Legközelebbi előfordulása Tornaszentjakab: Katalin-major (VoJTKó \& MARSCHALL 1997). MFA online: Tornaszentjakab (VV, SZF, 2004), Becskeháza (SZF, VV, 2003), Tornabarakony és Meszes (VA, 2004).

Waldsteinia geoides Willd. - Meszes: Nagy-Somos-hegy sziklásabb oldala (VA, 1996) [7590.4]; Viszló: Ubocs (FT, 2000) [7591.1]; Rakaca: Király-hegy északnyugati oldala (VA, MZ, 1996) [7591.1]; Rakacaszend: Gerenda-vigyor gyertyános-tölgyesben (VA, 2020) [7591.1]. Herb.: Rakacaszenden gyüjtötte Jakucs (1952, DE). MFA online: Tornaszentjakab (VV, SZF, 2004), Becskeháza (SZF, VV, 2003), Tornabarakony (VA, 2004). A teljes Cserehátban ritka.

\section{Köszönetnyilvánítás}

Kutatásainkat az Aggteleki Nemzeti Park Igazgatóság és Magyarország Flóratérképezési Programja támogatta. Köszönjük a közös terepi napokat és munkát Farkas Rolandnak, Marschall Zoltánnak és Penksza Károlynak. Köszönjük Virók Viktor és Molnár Csaba lektoraink jobbító észrevételeit.

\section{Irodalom}

BÁNKuTı K. \& VojтKó A. (1995): Adatok a Sonchus palustris L. elterjedéséhez. - Folia Historico-Naturalia Musei Matraensis 19: 47-49.

BUDAI J. (1914): Adatok Borsodmegye flórájához. - Magyar Botanikai Lapok 8: 312-326.

BARThA D., KiRÁly G., SCHMidT D., TiborCZ V., BARINA Z., CSIKY J., JAKAB G., LESKU B., SChMOTZER A., VidÉKi R., VojtKó A. \& ZólYomi Sz. (szerk.) (2015): Magyarország edényes növényfajainak elterjedési atlasza. Nyugat-magyarországi Egyetem Kiadó, Sopron, 329 p.

Boros Á. (1922): Florisztikai jegyzetek (“Útinapló") 7: 79-81.

Boros Á. (1937): Florisztikai jegyzetek ("Útinapló") 23: 242-243.

Boros Á. (1938): Florisztikai jegyzetek ("Útinapló") 24: 141-144.

BöLÖNI J. \& NAGY J. (1999): Szirti gyöngyvessző - Spiraea media Fr. Schm. - Tilia VII: 170-182.

DöVÉNYI Z. (szerk.) (2010): Magyarország kistájainak katasztere. - MTA Földrajztudományi Kutatóintézet, Budapest, 876 pp.

Endes M. (1995a): Kígyógyökerű keserűfű (Polygonum bistorta) a Tornai-dombságon. Florisztikai, ökológiai, cönológiai és természetvédelmi vonatkozások. - Calandrella 9(1-2): 89-92. 
VOJTKÓ \& FARKAS (2021): Florisztikai adatok Észak-Magyarországról II.

EnDES M. (1995b): Kapcsos korpafü (Lycopodium clavatum) a Tornai-dombságban. - Calandrella 9(1-2): 93.

ENDEs M. (1996): Csepleszmegy (Cornus fruticosa) a Szendrői rögvidéken. - Calandrella 10(1-2): 220.

EndEs M. (1997): Agárkosbor (Orchis morio) új színváltozata „Lusus georgiae”. - Calandrella 11(1-2): 94.

ENDES M. (2003a): A Rakaca patakvidék növénytársulásai. - Calandrella 12: 39-44.

EndEs M. (2003b): Új növénytársulás: a kígyógyökerű keserüfüves sásos (Carici-Polygonetum bistorta ass. nov. Endes), ÉK-Magyarország, Rakaca-patakvidék. - Calandrella 12: 45-47.

ENDES M., PAPP L. \& SzABÓ S. (2003a): A Rakaca-partvidék edényes flórája. - Calandrella 12: 82-95.

Endes M., PAPP L. \& SzABó S. (2003b): A Rakaca patakvidék Carex nemzetségéről. - Calandrella 12: 60-61.

ENDES M. \& SzABó S. (1996): Adatok a Tornai-dombság flórájához. - Calandrella 10(1-2): 222-223.

FARKAS J. (1996): Védett növények a Cserehát dombvidékén. - Kanitzia 4: 185-200.

FARKAS T. (2011): Adatok Borsod-Abaúj-Zemplén megye flórájához I. - Kitaibelia 15(1-2) [2010]: 167179.

FARKAS S. (szerk.) (1999): Magyarország védett növényei. - Mezőgazda Kiadó, Budapest, 416 p.

FEKETE G. \& JAKUCS P. (1957): Néhány karsztbokorerdő-faj elterjedési adatainak katalógusa Magyarországról. - Annales Historico-naturales Musei nationalis Hungarici 8: 181-195.

JAKUCS P. (1952): Új adatok a Tornai Karszt flórájához, tekintettel a xerotherm-elemekre. - Annales Biologicae Universitatum Hungariae 1 [1951]: 245-260.

JAKUCS P. (1952): Újabb adatok a Tornense flórájához. - Annales Biologicae Universitatus Hungaricae 2: 235-243.

JAKUCS P. (1961): Az Északi-Középhegység keleti felének növényzete. - Földrajzi Értesítő 10: 376-378.

KIRÁLY G. (2003): A magyarországi flóratérképezés módszertani alapjai. - Flora Pannonica 1(1): 3-20.

KIRÁLY G. (szerk.) (2009): Új magyar füvészkönyv. Magyarország hajtásos növényei. Határozókulcsok. Aggteleki Nemzeti Park Igazgatóság, Jósvafő, 616 pp.

MoLNÁR Cs. (2014): Florisztikai adatok a Harangod és a Dél-Cserehát löszvidékéről. - Kitaibelia 19(1): 105-113.

Molnár Cs., Lengyel A., Molnár V., Nagy T., Csábi M., Süveges K., Lengyel-Vaskor D., Tóth G. \& TaKács A. (2016): Pótlások Magyarország edényes növényfajainak elterjedési atlaszához II. - Kitaibelia 21(2): 227-252.

Molnár Cs., Haszonits Gy., Malatinszky Á., Süveges K., Balogh L., Nagy T., Horváth S. \& HudÁk K. (2018): Pótlások Magyarország edényes növényfajainak elterjedési atlaszához VI. - Kitaibelia 23(1): 87102.

MolNÁR V. A. (szerk.) (2011): Magyarország orchideáinak atlasza. - Kossuth Kiadó, Budapest, 504. p.

NAGY M. \& PAPP M. (1992): Az Alchemilla monticola Opiz új előfordulása a Csereháton. - Botanikai Közlemények 79: 29-35.

NAGY M. \& PAPP M. (1996): Studies in vegetationin Cserehát (North Hungary). - Thaiszia 6: 77-87.

NAGY M. \& PAPP M. (2003): A „Szemerei rét” növényzetéről. - Calandrella 12: 48-58.

NiKLfELD H. (1971): Berichtüber die Kartierung der Flora Mitteleuropas. - Taxon 20(4): 545-571.

PAPP M. \& NAGY M. (2003): A Fritillaria meleagris néhány morfológiai jellemzője és populációdinamikája a Rakaca-patak két láprétjén végzett vizsgálatok alapján. - Calandrella 12: 62-69.

PENKSZA K. (1998): A Sedo acris-Festucetum valesiacae ass. nov. a Rakacai-völgymedencében és a Cserehátban. - In: Csontos P. (szerk.), Sziklagyepek szünbotanikai kutatása. Scientia Kiadó, Budapest, pp. 77-88.

PEnKSZA K. \& MALATinSZKY Á. (2010): Adatok a Bódva-völgy edényes flórájához. - Botanikai Közlemények 97(1-2): 151-158.

PenksZA K. \& SAlAmon G. (1997a): Adatok a Cserehát, a Bódva-völgy és a Rakacai-völgymedence flórájához I. - Kitaibelia 2(1): 33-37.

Penksza K. \& SAlamon G. (1997b): Adatok a Cserehát, a Bódva-völgy és a Rakacai-völgymedence flórájához II. - Kitaibelia 2(2): 231-232.

Soó R., Boros Á., IgmÁndy J., MáTHÉ I. \& UJvÁRosi M. (1943): Előmunkálatok a Bükkhegység és környéke flórájához. - Botanikai Közlemények 40: 169-221.

SOMLYAY L. (2000): Adatok a Dunazug-hegység, a Tornai-karszt és környéke flórájához. - Kitaibelia 5(1): $47-52$. 
Szerdahelyi T. (2009): The Pteridophyte flora of the Gömör-Torna Karst Region. - In: PAPP B. (ed.), The Flora of the Aggtelek National Park. Cryptogams. Hungarian Natural History Museum, Budapest, pp. 231-243.

TAKÁCS A., SCHMOTZER A. \& SulYoK J. (2013): Florisztikai adatok a Sajó-Hernád-sík területéről. - Kitaibelia 18(1-2): 73-88.

TAKÁcS A., NAgY T., SRAmkó G., Lovas-Kiss Á., SÜVEgES K., LuKÁcs B., LÖKI V., MalatinsZKY Á., E-VojtKó A., Koscsó J. \& MolnáR V. (2016): Pótlások a Magyarország edényes növényfajainak elterjedési atlaszához I. - Kitaibelia 21(1): 101-115.

THAISz L. (1910): Adatok Abauj-Torna vármegye flórájához (II-ik közlemény). - Botanikai Közlemények 8: 217-221.

THAISz L. (1911): Adatok Abauj-Torna vármegye flórájához (III-ik közlemény). - Botanikai Közlemények 9: 122-130.

THAISz L. (1937): Abaúj-megye flórája. - Kézirat, Magyar Természettudományi Múzeum, Tudománytörténeti Gyüjtemény, Budapest.

ViRóK V. \& FARKAS R. (2007): Florisztikai adatok Borsod-Abaúj-Zemplén megye északi részéről II. Kitaibelia 12(1): 73-79.

Virók V., FARKAS R., SZMORAd F. \& BoldoghnÉ SzÛ́TS F. (2004): Florisztikai adatok Borsod-Abaúj-Zemplénmegye északi részéről I. - Kitaibelia 9(1): 143-150.

Virók V., FARKaS R., GulYás G. \& SRAmkó G. (2011): Florisztikai adatok Borsod-Abaúj-Zemplén megye északi részéről III. - Kitaibelia 15(1-2) [2010]: 73-84.

VIRÓK V., FARKAS R., FARKAS T., ŠUVADA R. \& VOJTKÓ A. (2016): A Gömör-Tornai-Karszt Flórája. Enumeráció. ANP Füzetek XIV., 200 pp. + CD melléklet.

Vojткó A. (2004): Az Aggteleki-karszt növényföldrajzi jellegzetességei. - Acta Academie Paedagogiace Agriensis Nova Series: Sectio Biologiae 25: 73-126.

VojTKó A. (2008): Florisztikai adatok Észak-Magyarországról. - Kitaibelia 13(1): 55-61.

VojTKó A. \& MARSCHALl Z. (1997): Adatok a Cserehát flórájához. - Kitaibelia 2(2): 252.

\section{Világháló-oldalak}

[1] BARThA D., BÁN M., Schmidt D. \& TiBorCz V. (2020): Magyarország edényes növényfajainak online adatbázisa (http://floraatlasz.uni-sopron.hu) - Soproni Egyetem, Erdőmérnöki Kar, Növénytani és Természetvédelmi Intézet. (Hozzáférés: 2020.12.11.)

Beérkezett / received: 2020. 11.27. • Elfogadva / accepted: 2021. 01. 17. 